the possibility of improper reporting of futures positions. The latter is illustrated by evidence that a large short elevator interest, by improperly reporting its futures positions as "hedges," was able to depress United States oats prices in the spring of 1952. ${ }^{97}$ Moreover, the Act obviously cannot handle attempts to corner the futures markets in commodities under its jurisdiction. An example of such an attempt may be inferred from the price gyrations in the March, 1953 onion future on the Chicago Mercantile Exchange..$^{98}$ It seems to be the opinion within the trade that an abortive attempt to corner that contract was responsible. ${ }^{99}$

That the latter problem has been recognized is indicated by a bill introduced in both Houses in 1949 which provided for the extension of the jurisdiction of the Act to eleven additional named commodities and to any other "agricultural or forest product" that the Secretary of Agriculture, after notice and hearing finds subject to futures trading under conditions requiring regulation. ${ }^{100}$ The bill never reached the floor. The problems of concerted activity and improper reporting are of a nature not amenable to legislative solution, but depend on the efficiency with which the Act is administered.

97 USDA, CEA, Investigation of Importation of Oats from Canada 1951-52. A complaint has been issued against Cargill, Inc., one of the largest cash grain firms in the United States. CEA Dkt. No. 58 (1952). Though a leader in the industry, it has had a checkered career on the Board of Trade. Compare In re Cargill, Inc. v. Board of Trade of City of Chicago, CEA Dkt. No. 6 (1940), with Secretary of Agriculture v. Cargill, Inc., CEA Dkt. No. 11 (1940). See also Cargill v. Board of Trade of City of Chicago, 164 F. 2d 820 (C.A. 7th, 1947), noted in Validity of Commodity Exchange Regulations under the Sherman Act, 16 Univ. Chi. L. Rev. 144 (1948). See also Cargill v. Commodity Exchange Commission, 103 F. Supp. 992 (D.C. D.C., 1952).

${ }^{93}$ See The Packer, p. 1, col. 5 (Apr. 4, 1953).

99 The statement of W. J. Piowaty, "one of the biggest onion men in the country" and a member of the Chicago Mercantile Exchange, in The Packer, p. 1, col. 4 (Apr. 11, 1953), entitled "Grief in Onions--Speculation Plus Long Supplies Equals Trouble" drew a fine of $\$ 200$ and suspended revocation of trading privileges by the Mercantile Exchange. See The Packer, p. 1, col. 4 (June 6, 1953); Chicago Sun-Times, p. 58, col. 5 (June 10, 1953); Chicago Tribune, Part 3, p. 6, col. 3 (June 10, 1953). For a description of the March, 1953 onion debacle, see The Packer, p. 1, col. 3 (Apr. 4, 1953).

${ }^{100}$ H.R. 4685, S. 1751 (1949); Report of the Administrator of the Commodity Exchange Authority 9 (1949); 95 Cong. Rec. 5388, 81st Cong., 1st Sess. (1949). A more recent proposal by Representative King of Pennsylvania was to insert the word "onion" in Section 2(a), 7 U.S.C.A. $\$ 2$ (1952), "so that onions are added to the definition of the word 'commodity" for the purposes of said Act." H.R. 6435, 83d Cong., 1st Sess. (July 21, 1953). See Chicago Daily News, p. 24, col. 1 (July 28, 1953).

\title{
EMPLOYEE STOCK OFFERINGS UNDER THE SECURITIES ACT-THE RALSTON PURINA CASE
}

In 1951, the Ralston Purina Company offered to sell 10,000 shares of its common stock to approximately 500 of its 7,000 employees without complying with the registration requirements of Section 5 of the Securities Act of 1933. ${ }^{1}$ In an

148 Stat. 77 (1933), as amended, 15 U.S.C.A. $\$ 77$ (1951). 
action by the Securities and Exchange Commission to enjoin the offering, Ralston Purina contended that its offering was exempt from the provisions of Section 5 by virtue of the so-called "private offerings" exemption of Section 4(1). ${ }^{2}$ The District Court and the Court of Appeals for the Eighth Circuit agreed with Ralston Purina. The Supreme Court, however, held the exemption inapplicable and enjoined the offering. SEC v. Ralston Purina Company. ${ }^{3}$

Ralston Purina based its contention that the private offerings exemption was applicable upon the fact that its offering was not made indiscriminately to all its employees but was, rather, restricted to those considered "key employees" by the management, ${ }^{4}$ although this category included many individuals quite low in the company organization. ${ }^{5}$ In holding the exemption inapplicable to employee offerings so restricted as well as to those made more or less indiscriminately, the Supreme Court's decision has imposed an important limitation upon the use of employee stock-investment plans. Corporations may be reluctant to attempt to put such plans into effect now that this type of offering may involve the expense and delays connected with the Section 5 registration process. ${ }^{6}$

That employee stock offerings were never intended to receive a blanket exemption from registration is shown by the legislative history of Section 4(1). In rejecting a 1934 amendment designed expressly to exempt all employee stockinvestment plans, ${ }^{7}$ conferees of both Houses of Congress indicated their feeling that

the participants in employees' stock-investment plans may be in as great need of the protection afforded by the availability of information concerning the issuer for which they work as are most other members of the public. ${ }^{8}$

348 Stat. 77 (1933), as amended, 15 U.S.C.A. $\$ 77 d(1)$ (1951). The second clause of the section exempts "transactions by an issuer not involving any public offering."

3346 U.S. 119 (1953), rev'g 200 F. 2 d 85 (C.A. 8th, 1952) and 102 F. Supp. 964 (E.D. Mo., 1952). The Court of Appeals decision is noted in 66 Harv. L. Rev. 1144 (1953); 39 Va. L. Rev. 376 (1953). The District Court decision is noted in 51 Mich. L. Rev. 597 (1953); 21 Fordham L. Rev. 183 (1952). For a report on the oral argument before the Supreme Court, see 21 U.S.L. Week 3281-82 (1953).

1 The issuer's definition of the term is of interest: "It would include an individual who is eligible for promotion, an individual who especially influences others or who advises others, a person whom the employees look to in some special way, an individual, of course, who carries some special responsibility, who is sympathetic to management and who is ambitious and who the management feels is likely to be promoted to a greater responsibility." See 346 U.S. 119, 122 (1953).

s See page 116 infra.

- See Loss, Securities Regulation 244-47 (1951).

7 The amendment, as proposed by Senator Hastings, would have added the following to $8(1)$ : "As used in this paragraph, the term 'public offering' shall not be deemed to include an offering made solely to employees of an issuer or of its affiliates in connection with a bona fide plan for the payment of extra compensation or stock-investment plan for the exclusive benefit of such employees." 78 Cong. Rec. 8,708 (1934).

H.R. Rep. No. 1,838, 73d Cong. 2d Sess. 41 (1934). Senator Fletcher, one of the conferees, made a conflicting statement in debate on the floor of the Senate, indicating his im- 
If an employee stock offering is not exempt per se under Section 4(1), the crucial question presented in the Ralston Purina case arises: What is the appropriate standard for selecting employee-offerees who may be the object of a "private offering" by the employer-issuer?

Justice Clark bases his formulation of such a standard upon the observations on the distinction between "public" and "private" made by Judge Denman of the Court of Appeals for the Ninth Circuit in SEC v. Sunbeam Gold Mines, ${ }^{9}$ which involved an offering by an issuer to its stockholders. ${ }^{10}$

Judge Denman set forth the purpose of the Securities Act as stated in its title: "To provide full and fair disclosure of the character of securities sold in interstate and foreign commerce and through the mails, and to prevent frauds in the sale thereof. ..."' $\mathrm{He}$ then continued:

Such an offering, though not open to everyone who may choose to apply, is none the less "public" in character, [when] the means used to select the particular individuals to whom the offering is to be made bears no sensible relation to the purposes for which the selection is made.... To determine the distinction between "public" and "private" in any particular context, it is essential to examine the circumstances under which the distinction is sought to be established and to consider the purposes sought to be achieved by such distinction. ${ }^{22}$

As Justice Clark pointed out in his opinion, the courts below had purported to apply Judge Denman's definition to the Ralston Purina offering, considering the issuer's desire to create employee incentive through stock ownership as the purpose for which the selection of offerees was made. Viewed in this way, the issuer's definition of a key employee as one "sympathetic to management and ... likely to be promoted to a greater responsibility"1z clearly qualifies as a valid standard of selection, inasmuch as it bears a direct relationship to the issuer's incentive-stimulation motive.

Justice Clark, however, rejected the lower court's initial assumption that the reasonableness of the selection in relation to the offeror's purpose is the proper

pression that the conferees had rejected the Hastings amendment because employee stockinvestment plans were exempt from registration without it. 78 Cong. Rec. 10,182 (1934). However, all other statements made in Senate debate were in apparent harmony with the view expressed in the conference report. See remarks of Senator Couzens, ibid., at 10,181. See also 77 Cong. Rec. 2,915 (1933); Interpretation of the "Public Offering" Exemption of the Federal Securities Act and State Blue-Sky Laws, 36 Mich. L. Rev. 604, 608 n. 36 (1938). Justice Clark indicated in Ralston Purina that the statement of the conference report is "entitled to more weight than different views expressed by one of the conferees in Senate debate." 346 U.S. 119, 126 n. 13 (1953). See also Loss, Securities Regulation 397 n. 324 (1951).

995 F. 2 d 699 (C.A. 9th, 1938).

${ }^{10}$ The offerees included some persons who were holders of stock in a corporation with which the issuer was planning a merger. This fact-that the offering was not limited to the issuer's stockholders-was important in leading to the court's holding that the offering was
public.

1148 Stat. 74 (1933).

12 SEC v. Sunbeam Gold Mines, 95 F. 2d 699, 701 (C.A. 9th, 1938).

${ }^{13}$ See note 4 supra. 
criterion. Instead, he reasoned that since the Securities Act has as its primary purpose the protection of the investor, ${ }^{14}$ the entire selection process must be viewed from the standpoint of the offerees and their protection rather than from that of the issuer and its motives and hopes for gain. Thus, the applicability of the exemption "should turn on whether the particular class of persons affected needs the protection of the Act."15 Clearly, where the offerees are initially in possession of substantially the same information concerning the issuer which registration would disclose, the protection usually afforded by registration becomes superfluous.

Applying this reasoning to the Ralston Purina case, Justice Clark found that the issuer's key-employee standard of selection was such as would-and didpermit the selection of offerees not likely to have access to such information as would serve as an adequate substitute for the information to be derived from registration, and not, in fact, shown to have had such access. This conclusion would appear highly justified by the list of positions held by Ralston Purina offerees, which included an artist, clerical assistant, electrician, stock clerk, stenographer, and others of like status and lack of access. ${ }^{16}$

Justice Clark's test has the virtue of not ruling out a private offering in the case of a stock-investment plan for corporate executives, insofar as the executive can usually be expected to possess a degree of knowledge of the corporation's affairs and financial condition sufficient to render unnecessary the protection which registration disclosure might provide. This point of view has expressly been taken by Massachusetts and Indiana statutes. Since 1938, the Massachusetts blue-sky law has prohibited the sale or offering by a corporation of any of its securities "to any of its employees other than those who are also officers thereof," without the express consent of the state commission. ${ }^{17}$ In 1951, Indiana adopted a provision exempting from the operation of its securities law a corporation's sale of its securities to a director or executive officer, provided that "such person directly participate in the formulation of corporation policy."18

The substance of Justice Clark's analysis was advanced by the Commission as early as 1935, in an interpretative opinion by its General Counsel ${ }^{19}$ indicating various factors to be considered in determining whether an offering is public or

${ }^{14}$ See 346 U.S. 119, 124 (1953).

${ }^{15}$ Ibid., at 125.

${ }^{16}$ For a full listing of the nature of the positions held by the offerees, see Brief for Appellant at 6-8, SEC v. Ralston Purina Co., 200 F. 2d 85 (C.A. 8th, 1952). For cases indicating the "quality" of access required, see Campbell v. Degenther, 97 F. Supp. 975 (W.D. Pa., 1951); SEC v. Federal Compress \& Warehouse Co., ' $41-' 44$ CCH Fed. Sec. L. Decisions $\$ 90,106$ (W.D. Tenn., 1936); Cristina Copper Mines, Inc., SEC Sec. Act Release No. 3,439, CCH Fed. Sec. L. Rep. $\llbracket 76,113$ (1952).

${ }^{17}$ Mass. Ann. Laws (Supp., 1952) c. 110A, \$11E.

18 Ind. Stat. Ann. (Burns, Supp., 1952) § 25-833 (n).

${ }^{19}$ SEC Sec. Act Release No. 285 (1935), 11 Fed. Reg. 10,952-53 (1946). 
private. It is important to consider the effects of the Counsel's opinion in view of the great weight which the Supreme Court has indicated is to be given to administrative interpretations of this type. ${ }^{20} \mathrm{In}$ effect, this early opinion indicated that the relationship of offerees to issuer-and thus the knowledge of the offerees-"would be particularly important in offerings to employees, where a class of high executive officers would have a special relationship to the issuer which subordinate employees would not enjoy."21

Justice Clark discussed briefly one factor which had been designated by the Commission in its 1935 opinion $^{22}$ and its brief in the Ralston Purina case: the number of offerees. ${ }^{23}$ This factor he rejected, seeing "no warrant for superimposing a quantity limit on private offerings as a matter of statutory interpretation."24 In so doing, however, Justice Clark indicated that the Commission was not prohibited from using a numerical test as an administrative guide for determining those offerings which it feels warrant investigation. While the knowledge of the offerees is properly the ultimate test, the number of offerees would appear to be a good warning that such knowledge is not present in a particular offering. ${ }^{25}$

While the Court's decision in the Ralston Purina case should be approved as

${ }^{20}$ Such opinions have been said to be "of persuasive force," United States v. Madigan, 300 U.S. 500, 505 (1937); to constitute "highly relevant and material evidence of the probable general understanding of the times," Shapiro v. United States, 335 U.S. 1, 12 n. 13 (1948), quoting from White v. Winchester Club, 315 U.S. 32, 41 (1942); and to be "entitled to great weight," Roland Electrical Co. v. Walling, 326 U.S. 657, 676-77 (1946), quoting from United States v. American Trucking Ass'ns, 310 U.S. 534, 549 (1940). Perhaps the most forceful statement is provided by Judge Augustus Hand, regarding a similar interpretative release by the SEC, in SEC v. Associated Gas \& Electric Co., 99 F. 2d 795, 798 (C.A. 2d, 1938): "One of the principal reasons for the creation of such a bureau [as the SEC] is to secure the benefit of special knowledge acquired through continuous experience in a difficult and complicated field. Its interpretation of the act should control unless plainly erroneous."

${ }^{21}$ SEC Sec. Act Release No. 285 (1935), 11 Fed. Reg. 10,952 (1946), quoted in SEC v. Ralston Purina Co., 346 U.S. 119, 125 n. 12 (1953).

${ }^{2}$ In Sec. Act Release No. 285, the Commission advanced the idea that offerings to fewer than 25 persons should be deemed private. Two states have enacted similar provisions. In Colorado, an offering is deemed to be made "to the general public" where it is made to more than 50 persons. Colo. Stat. Ann. (1935) c. 148, $\$ 14$ (3). Virginia exempts sales to fewer than 30 persons. Va. Code (1950) $\$ 13-113(14)$. Some 18 states exempt the offering of stock to a corporation's incorporators, some without a limitation on the number of incorporators and others limiting the number, with limits ranging from 5 to 25 .

${ }^{23}$ However, the Commission had apparently disclaimed any intention of creating a fixed numerical standard. See Oral Argument before Supreme Court, 21 U.S.L. Week 3281 (1953), and Cristina Copper Mines, Inc., SEC Sec. Act Release No. 3,439, CCH Fed. Sec. L. Rep. II 76,113 (1952).

24346 U.S. 119, 125 (1953).

${ }^{25}$ Another administrative guide advanced by the Commission in its 1935 opinion is that of manner of offering. Where a public means of advertising is employed, it is less likely that the offerees reached will possess the requisite knowledge than where informal means of communications are employed. But the manner of offering although indicative cannot be decisive, is illustrated by the Ralston Purina case, where only the most informal means of communication were used. 
consistent with the purpose of the Securities Act, it cannot be taken as a solution of all employee-offering problems which may arise. An area in which the effect of the entire complex of facts is all-important can scarcely be susceptible to comprehensive self-executing regulation. Desirable as certainty may be, each case will in large measure create its own rule, with the over-all purpose of the Act as the principal guide.

\section{SUPERVISION OF CHARITABLE TRUSTS}

In 1943, New Hampshire became the first state to establish a comprehensive system for the enforcement and supervision of charitable trusts. ${ }^{1}$ Through enforcement of the donor's intent, mismanagement of trusts has been corrected, and several millions of dollars in previously dormant trust funds have been put to use for the benefit of the state's inhabitants. ${ }^{2}$ The present inquiry will be directed to an examination of the reasons why similar legislation should be adopted by other states; ${ }^{3}$ it will also make definite suggestions regarding the type of "Model Supervision of Charitable Trusts Act" which should be offered to the states by the Uniform Law Commissioners. ${ }^{4}$

A charitable trust is a fiduciary relationship created by the expression of a charitable intent in a will, indenture, or corporate charter. This relationship is present whether the charity is large or small ${ }^{5}$ and whether the class of persons benefited is broad or narrow. ${ }^{6} \mathrm{It}$ is essential that every state provide some system for supervising trustees because the nature of charitable trusts creates a special handicap to the enforcement of the charitable purpose stated in the creating instrument. Normally enforcement of the civil law is predicated on the assumption that when a breach of a legal obligation occurs, the injured party, motivated by his own self-interest, will inform the court of the breach and de-

1 N.H. Rev. Laws 1943, c. 24, \& 13a-13n.

${ }^{2}$ Letter from N.H. Dir. of Char. Trusts (March 25, 1953). This letter and others cited hereafter were received in reply to questionnaires sent to the Attorneys General of states which had provided or were about to provide comprehensive reform, as well as to the "partial reform" states. This material and all legislative and executive papers are on file at the Council of State Governments (Project File: Charitable Trusts, 1953), 1313 E. 60th St., Chicago, Ill.

${ }^{3}$ R.I. Pub. Laws, c. 2617 (1950) established a similar system of state supervision for Rhode Island.

1 On August 8, 1953, the National Association of Attorneys General requested the Uniform Law Commissioners to suggest state legislation concerning regulation of charitable trusts. Alternative preliminary drafts were submitted to the National Association, and on December 10,1952 , that group resolved that the development of alternative "Uniform Acts" which provide for either permissive or mandatory regulation "would enable the states to select the form which best meets their individual needs and requirements." Proceedings of the Conference of the National Association of Attomeys General 155 (1952).

s 3 Scott, Trusts $\$ 375.1$ (1939).

Ibid., at \$375.2. 